\title{
Tanggapan Masyarakat terhadap Pondok Pesantren Darul Ilmi dalam perspektif pendidikan
}

\author{
Muhammad Efendi* \\ Program Studi Geografi, FISIP Universitas Lambung Mangkurat \\ Banjarmasin, Indonesia \\ muhammad.efendi@ulm.ac.id \\ Kukuh Ranom Prayoga \\ Fakultas Tarbiyah dan Keguruan, UIN Antasari \\ Banjarmasin, Indonesia \\ kukuhprayoga10@gmail.com \\ Muniratul Mukaramah \\ Kementerian Agama Republik Indonesia, Madrasah Aliyah Darul Ilmi \\ Banjarbaru, Indonesia \\ mukaramah04@gmail.com
}

\begin{abstract}
Islamic boarding schools are part of educational institutions that seek to foster, educate, guide, and develop every potential that exists in humans. The extent to which Islamic boarding schools play a role in the field of education will continue to be assessed by the community who always expects the creation of a prosperous environment and the fulfillment of the needs of the religious sector. Community response is a factor that determines the success or failure of Islamic boarding schools in fostering their students. This study focuses on the community's response to the Darul Ilmi Islamic boarding school from the perspective of Islamic religious education. The method used in this research is a qualitative approach. The data was collected using observation, interview, and documentation techniques. The object of this research is the public's perception of Islamic religious education in Darul Ilmi Islamic Boarding School. The subjects of this study were the people of the Landasan Ulin Barat village, RT. 09, while the data analysis used is descriptive qualitative. The result of this study is the public's assessment that the Darul Ilmi Islamic boarding school in Banjarbaru City has been successful and effective in providing Islamic religious education to its students.
\end{abstract}

Keywords: Response; Islamic Boarding School; Education

\begin{abstract}
Abstrak
Pondok pesantren merupakan bagian dari lembaga pendidikan yang berupaya membina, mendidik, membimbing dan mengembangkan setiap potensi yang ada di dalam diri manusia. Sejauh mana pondok pesantren berperan dibidang pendidikan akan terus dinilai oleh masyarakat yang senantiasa mengharapkan terciptanya lingkungan yang sejahtera dan terpenuhinya kebutuhan disektor keagamaan. Tanggapan masyarakat menjadi faktor yang menentukan berhasil atau tidaknya pondok pesantren dalam membina santri-santrinya.
\end{abstract}


Penelitian ini berfokus pada Tanggapan masyarakat terhadap pondok pesantren Darul Ilmi dalam perspektif pendidikan. Penelitian ini menggunakan pendekatan kualitatif. Peneliti menggunakan teknik observasi, wawancara dan dokumentasi dalam mengumpulkan data lapangan. Objek dalam penelitian ini adalah ponpes Darul Ilmi yang berhubungan dengan bagaimana tanggapan masyarakat terhadap lembaga tersebut. Subjek penelitianya adalah masyarakat yang berada di kelurahan Landasan Ulin, selanjutnya analisis data yang digunakan adalah deskriptif kualitatif. Adapun hasil dari penelitian ini berupa penilaian masyarakat bahwa pondok pesantren Darul Ilmi kota Banjarbaru sudah berhasil dan tepat guna dalam memberikan pendidikan agama Islam kepada para santrinya.

Kata Kunci: Tanggapan; Pondok Pesantren; Pendidikan

Diterima 30 September 2021, Dipublikasikan 30 Oktober 2021

\section{PENDAHULUAN}

Pendidikan dapat diartikan sebagai bagian dari suatu rangkaian belajar yang dilakukan oleh pelajar atau bersama orang lainnya untuk mengontrol, memandu, mengarahkan, mempengaruhi, dan mengelola situasi belajar agar dapat meraih hasil yang ingin dicapai (Pandiangan, 2019). Pendidikan bertujuan untuk mempersiapkan hidup dalam masyarakat, di mana peserta didik itu sendiri berasal dari masyarakat, dididik oleh masyarakat, dan harus kembali ke masyarakat (Arifin, 2011). Fungsi dan tujuan pendidikan nasional termaktub dalam Undang-Undang No. 20 tahun 2003 Bab II pasal 3 yang menjelaskan bahwa pendidikan nasional berfungsi mengembangkan kemampuan dan membentuk watak serta peradaban bangsa yang bermartabat dalam rangka berupaya mencerdaskan kehidupan bangsa, bertujuan untuk berkembangnya potensi peserta didik agar menjadi insan yang beriman dan bertakwa kepada Tuhan yang Maha Esa, berakhlak mulia, sehat, berilmu, cakap, kreatif, mandiri dan menjadi warga negara yang demokratis serta bertanggung jawab.

Tercapainya fungsi dan tujuan pendidikan dapat diwujudkan dengan beberapa jalur yang menyediakan kegiatan pendidikan yang diperoleh peserta didik untuk mengembangkan potensi diri yang sesuai dengan tujuan pendidikan nasional (Efendi, 2014), hal ini dinyatakan dalam Undang-Undang No.20 tahun 2003 Bab I pasal 1 tentang sistem Pendidikan Nasional adalah sebagai berikut: (1) pendidikan formal merupakan jalur pendidikan yang berjenjang dan terstruktur terdiri atas pendidikan dasar, pendidikan menengah dan pendidikan tinggi, (2) pendidikan nonformal adalah pendidikan di luar jalur pendidikan formal yang dapat dilaksanakan secara terstruktur dan berjenjang, (3) pendidikan Informal adalah jalur pendidikan keluarga dan lingkungan (Indonesia, 2003).

Tidak kalah pentingnya, pendidikan keagamaan mempersiapkan warga belajar untuk dapat menjalankan peranan yang menuntut penguasaan khusus tentang ajaran agama berupa pendidikan yang diselenggarakan melalui kelompok belajar, kursus-kursus, kelompok bermain, pondok pesantren, majelis taklim dan lain-lain (Jamal, 2015). Pondok Pesantren menjadi lembaga yang memiliki banyak pengaruhnya terhadap perkembangan ilmu keislaman 


\section{Tanggapan Masyarakat Terhadap Pondok Pesantren Darul Ilmi ...}

di Indonesia (Nasution, 2020). Pondok Pesantren adalah suatu lembaga pendidikan di Indonesia yang memberikan pendalaman ilmu keagamaan dan pengamalannya (Syafe'i, 2017).

Keberadaan pondok pesantren tidak dapat dilepaskan dengan keberadaan masyarakat dan karena itu pondok pesantren harus akomodatif terhadap tuntutan masyarakat (Herdiana et al., 2021). Upaya pengembangan pondok pesantren tidak terlepas dari peran serta masyarakat dan akan menimbulkan potensi yang positif dalam pengembangan pondok pesantren kedepannya, dengan catatan pondok pesantren harus mampu bersinergi serta mengedepankan aspirasi masyarakat sekitar, baik sebagai bahan evaluasi maupun kontrol dalam pengembangan pondok pesantren kedepannya (Suhardi \& Irawan, 2015). Wujud pondok pesantren yang bersikap tanggap terhadap masyarakat sekitar dengan memanfaatkan pendekatan sosial inteligence akan memunculkan efek positif dalam persepsi masyarakat hal ini mampu mewujudkan kelancaran pelaksanaan kegiatan pembelajaran, keagamaan, sosial maupun kegiatan yang berhubungan langsung dengan masyarakat (Kurniawan, 2021).

Keberadaan pesantren dari segi akademik dapat dilihat dari berbagai macam perspektif, mulai dari kurikulum, tingkat kemajuan dan kemodernan, keterbukaan terhadap perubahan dan dari perspektif sistem pendidikannya (Shiddiq, 2015). Berkembangnya pola pikir masyarakat dewasa ini memberikan pengaruh yang signifikan bagi pesantren dalam menciptakan inovasiinovasi sebagai upaya meningkatkan kualitas pendidikan. Pendidikan pesantren di era globalmultikultur ini idealnya bersikap aktif terhadap perkembangan ilmu pengetahuan, menumbuhkan daya saing, tetapi tetap mampu mempertahankan pembinaan moral yang selama ini dianggap prestasi besar pondok pesantren (Arifiah, 2021).

Mengacu hasil penelitian Arifin \& Syafi'i (2003) beliau menegaskan bahwa pesantren adalah lembaga pendidikan islam yang terus berkembang dan diakui masyarakat dilingkungannya. Pondok pesantren dalam perkembanganya dari dahulu hingga sekarang tidak pernah lepas dari subtansi keilmuan agama dengan menggunakan sistem asrama yang memisahkan antara santri putra dengan santri putri serta memiliki metode pembelajaran klasik yaitu pengajian yang sepenuhnya berada dalam kontrol dan pengawasan kiai (pengasuh maupun pendiri) dengan ciri memiliki karismatik serta independen dalam berbagai hal.

Berdasarkan paparan di atas dapat ditarik kesimpulan bahwa pesantren adalah suatu lembaga pendidikan Islam yang mengajarkan dan menyebar luaskan ajaran Islam serta melatih santri untuk siap dan mandiri dalam menjalani hidup. Dapat diartikan juga bahwa pesantren merupakan tempat belajar para santri pada kiai untuk memperdalam dan menambah ilmu pengetahuan agama Islam. Pesantren sebagai lembaga pendidikan non formal hanya mempelajari ilmu agama yang bersumber dari kitab-kitab klasik (Efendi et al., 2020). Adapun kurikulumnya mencakup mata pelajaran keislaman seperti ilmu Tauhid, ilmu Tafsir, Hadits, ilmu Hadits, ilmu Akhlaq, ilmu Fiqh, Ushul al- Fiqh, ilmu Tasawuf. Bahasa Arab yang mencakup Nahwu, Sharaf, Badi', Balaghah, Bayan, Mantiq dan Tajwid (Anhari, 2007). Pesantren sebagai lembaga pendidikan memiliki tanggung jawab pada proses pencerdasan bangsa secara integral. Secara khusus pesantren bertanggung jawab terhadap berlangsungnya 
tradisi keagamaan dalam kehidupan masyarakat. Tujuan pesantren dalam kaitan dua hal tersebut adalah membentuk manusia mukmin yang memiliki moral dan intelektual yang berkualitas (Tolib, 2015).

Islam memberikan penjelasan mengenai kebutuhan dasar manusia. Manusia memiliki unsur jasmani dan rohani yang sama-sama memiliki kebutuhan tersendiri. Pemenuhan kebutuhan agama sebagai makhluk Allah SWT (Arifin, 2009). Dari segi rohani maupun jasmani. Kebutuhan beragama menjadi bagian dari fitrah manusia yaitu naluri beragama yang di dalamnya terdapat benih-benih religiusitas manusia. Mempersiapkan masyarakat yang madani memang perlu adanya partisipasi aktif dari pendidikan yang begitu besar. Peran lembaga pendidikan khususnya pesantren yang dituntut lebih dalam pembinaan keimanan dan pengimplementasian ilmu keagamaan (Arifiah, 2021).

Keberadaan masyarakat begitu penting bagi keberlangsungan kiprah pondok pesantren. Senada dengan hasil penelitian suharni dan hermawan (2020) yang mengatakan bahwa arus perkembangan zaman menjadi faktor utama meningkatnya kebutuhan dan tuntutan masyarakat terhadap pendidikan pesantren, serta degradasi keilmuan keagamaan pada jaman milenium sekarang ini sungguh memprihatinkan. Hal ini kiranya menjadi perhatian bagi pondok pesantren untuk lebih meningkatkan peranannya bagi masyarakat.

Mengacu hasil penelitian Pratama (2014) yang menyatakan bahwa era globalisasi memberikan tantangan baru bagi pondok pesantren dalam memenuhi kebutuhan dan tuntutan masyarakat. Dewasa ini, banyak sekali pondok pesantren yang melakukan terobosan baru seperti memperbaiki kurikulum pendidikan, sarana dan prasarana, serta tenaga pendidik (Tolib, 2015). Pondok pesantren harus berupaya mencari pembaharuan yang tepat agar menghasilkan produk-produk cendekiawan muslim yang bermutu (Fakhruddin, 2011). Pondok Pesantren Darul Ilmi Banjarbaru menjadi lembaga pendidikan Islam yang berupaya menghasilkan generasi-generasi dengan potensi diri yang unggul dan berkompeten sehingga dapat menjadi jawaban bagi segala kebutuhan serta tuntutan yang ada di masyarakat. Sejauh pengamatan peneliti terhadap peranan ponpes Darul Ilmi sudah sangat membantu masyarakat sekitar dalam memenuhi keperluan-keperluan yang menyangkut masalah keagamaan. Santri diundangan untuk mengisi kegiatan keagamaan seperti; tahlilan, pembacaan maulid habsyi, kegiatan haul, menyalatkan jenazah dan lain sebagainya (Prayoga, 2021). Hal ini menjadi bukti bahwa para santri pondok Pesantren Darul Ilmi Banjarbaru cukup mumpuni untuk memenuhi kebutuhan masyarakat sekitar.

Berdasarkan paparan diatas, penulis mencoba mengali lebih dalam terkait persepsi masyarakat terhadap ponpes Darul Ilmi dengan memperhatikan peranan ponpes yang sudah banyak memberikan sumbangsih dalam memenuhi kebutuhan masyarakat. Berawal dari siniliah penulis akan mengemati dan meneliti peran serta dan keterlibatan ponpes dalam menyiapkan kebutuhan masyarakat pada bidang keilmuan dan pendidikan islam di kelurahan Landasan Ulin Barat Rt 09. Kota Banjarbaru. 


\section{Tanggapan Masyarakat Terhadap Pondok Pesantren Darul Ilmi ...}

\section{METODE}

Metode penelitian yang penulis gunakan adalah penelitian lapangan, dengan pendekatan kualitatif, yang menekankan pada analisis data lapangan yang akan diolah selanjutnya disimpulkan dalam bentuk uraian maupun penjabaran deduktif maupun induktif yang tetap berpegang pada kajian ilmiah (Sugiyono, 2008). Keberadaan peneliti di lapangan adalah bagian dari pengisian instrumen serta tahapan pengumpul data yang kemudian akan diolah menjadi hasil penelitian dan selanjutnya dilakukan analisis serta disimpulkan.

Penelitian ini ditujukan untuk menjawab pertanyaan tentang apa dan bagaimana keadaan di lokasi penelitian serta melaporkan apa adanya. Selanjutnya penulis akan mendeskripsikan bagaimana tanggapan masyarakat terhadap pendidikan keagamaan di ponpes Darul Ilmi, dengan metode deskriptif yang memfokuskan pada fenomena maupun kejadian kedalam bentuk persepsi maupun tanggapan masyarakat terhadap peran serta dan keberadaan pendidikan agama di ponpes Darul Ilmi yang disajikan melalui paparan faktual dilapangan dengan cermat. Adapun yang menjadi subjek pada penelitian ini adalah masyarakat kelurahan Landasan Ulin barat RT. 09 kecamatan Liang Anggang kota Banjarbaru dengan 25 orang dari 152 warga yang berusia dari 20-50 tahun, dalam hal ini dijadikan sumber utama sebagai data pokok, kemudian untuk mendukung kajian diperlukan data penunjang yang diperoleh dari pimpinan ponpes serta masyarakat pembelajar di lingkungan ponpes Darul Ilmi yang meliputi; (1) guru, (2) pimpinan lembaga, (3) ustadz dan (4) staf tata usaha.

Pengambilan data di lapangan dengan metode wawancara terbuka, tidak semuanya masyarakat yang ada di RT. 09 kelurahan Landasan Ulin Barat dijadikan sampel akan tetapi jika jawaban informan sudah jenuh maka peneliti berhenti sampai disitu, kemudian data di olah dan dianalisis secara interaktif. Analisis data dilakukan setiap saat pengumpulan data di lapangan secara berkesinambungan. data berupa kalimat yang dikumpulkan lewat observasi, angket, dokumentasi dan lain-lain telah disusun dengan teratur, selanjutnya menurut Miles dan Huberman (1992) dalam proses analisis data terdapat tiga komponen utama yang benar-benar harus dipahami oleh setiap peneliti kualitatif, yaitu (1) reduksi data, (2) sajian data, (3) penarikan kesimpulan atau verifikasi.

Selanjutnya dalam tahapan penelitian penulis melakukan tiga teknik dalam pengumpulan data, yaitu; (1) observasi awal dengan mengamati proses pendidikan yang dujalankan di ponpes Darul Ilmi dan keadaan masyarakat sekitar, (2) berikutnya teknik wawancara, penulis menggunakan metode ini sebagai upaya pengumpulan data dengan melakukan tanya jawab kepada pimpinan ponpes, kepala sekolah, tenaga pendidik, dan masyarakat sekitar yang sesuai dengan tujuan penelitian, dan (3) dokumentasi, penulis menggunakan metode ini untuk mendapatkan data seperti halnya sejarah berdirinya ponpes, kualifikasi pengajar, karyawan, keadaan santri serta sarana dan prasarana yang tersedia di lembaga ponpes Darul Ilmi. 


\section{HASIL DAN PEMBAHASAN}

Pengembangan pendidikan dan pengajaran yang dilakukan oleh Pondok Pesantren Darul Ilmi Banjarbaru dengan perlahan tapi pasti mengalami kemajuan yang cukup signifikan. Kemajuan yang dimaksud adalah dengan adanya pengadaan sarana dan prasarana, perekrutan tenaga pendidik dan staf serta peningkatan jumlah santri atau siswa baru dari tahun ke tahun. Jika menilik letak Pondok Pesantren Darul Ilmi yang berada di ibu kota Banjarbaru, tentunya persaingan antar lembaga pendidikan begitu sangat terasa. Perbandingan yang mencolok antara Pondok Pesantren Darul Ilmi dengan sekolah-sekolah yang berstatus negeri tentunya menjadi tolak ukur bagi masyarakat untuk memasukkan anaknya ke ponpes Darul Ilmi. Hal ini seperti yang dikatakan oleh Pimpinan ponpes Darul Ilmi jika untuk bersaing dengan sekolah-sekolah negeri dan juga sekolah unggulan seperti SMA Banua tentunya pondok kita ini masih cukup tertinggal (Mahmud, 2021).

Seiring berjalannya waktu, ponpes Darul Ilmi terus melakukan perbaikan dan pengembangan untuk meningkatkan kualitas pendidikan sehingga dapat menarik minat masyarakat untuk memasukkan anak-anaknya menimba ilmu di sana (Arisanty \& Efendi, 2017). Ustadz Safwani Karani, selaku kepala sekolah mengatakan bahwa pondok melakukan beberapa kegiatan yang melibatkan santri-santrinya terjun langsung tengah masyarakat sebagai bentuk pengabdian serta melatih para santri dalam bersosialisasi di lingkungan masyarakat. Pada tanggal 20 Februari-10 Maret 2021 dilaksanakan kegiatan Darul Ilmi Mengabdi (DAIM) di kota Palangkaraya Kalimantan Tengah, beliau juga menambahkan jika masyarakat begitu antusias menyambut santri yang nantinya akan melakukan kegiatan keagamaan di sana. Untuk wilayah sekitar ponpes Darul Ilmi sendiri pihak pondok memberikan keluwesan kepada masyarakat apabila hendak mengundang santri untuk menghadiri atau mengisi acara keagamaan.

Keperluan masyarakat terhadap sosok yang dapat memimpin ritual-ritual ibadah keagamaan menjadikan kehadiran santri ponpes Darul Ilmi begitu penting dimata masyarakat. Sebagaimana yang dituturkan oleh masyarakat dilingkungan pondok sebagai berikut: "Kita sering mengundang santri-santri Darul Ilmi untuk tahlilan, maulid habsyi. Banyak lagi yang bisa dimintai bantuan kepada mereka untuk acara-acara agama” (Masinah, 2021), berdasarkan penuturan beliau, kita dapat melihat bersar harapan masyarakat kepada santri di pondok pesantren Darul Ilmi untuk dapat menjadi panutan ketika nantinya terjun ke lingkungan masyarakat. Bapak Suraji juga mengatakan: "Anak saya di sekolahkan di situ, alhamdulillah sekarang mengaji lancar, doa-doa banyak yang dia hafal. Kami orang tua bersyukur sekali anak-anak kami nantinya bisa mendoakan orang tua jika sudah meninggal" (Suraji, 2021).

Selanjutnya ibu Nissa menuturkan: "Dari yang saya lihat, Darul Ilmi sudah cukup berhasil dalam mendidik santri-santrinya”. Dapat dipahami berdasarkan penjelasan masyarakat di atas, jika masyarakat menganggap Pondok Pesantren Darul Ilmi telah mampu memberikan pendidikan kepada santrinya sesuai dengan yang orang tua mereka harapkan dan masyarakat pun menaruh kepercayaan yang tinggi kepada Pondok Pesantren Darul Ilmi sebagai lembaga 


\section{Tanggapan Masyarakat Terhadap Pondok Pesantren Darul Ilmi ...}

pendidikan. Mengenai hal ini bapak Hidayat selaku pengurus data santri menuturkan jika setiap tahunnya terjadi peningkatan jumlah santri yang mendaftar dan diterima di Pondok Pesantren Darul Ilmi Banjarbaru.

Menurut Himran (2021) jika melihat kebelakang, alumni ponpes Darul Ilmi, sudah tersebar kebeberapa daerah baik kalimantan selatan secara umumnya maupun pulau sulawesi secara khusunya, beliau (pimpinan pondok) menyampaikan bahwa "tidak sedikit santri-santri yang dulu pernah menempuh pendidikan di Pondok Pesantren Darul Ilmi kini telah menjadi orang penting di lingkungan masyarakatnya seperti menjadi tuan guru di daerahnya, menjadi anggota dewan, pedagang yang bersahil dan masih banyak lagi”. Hal ini menjadi bukti jika ponpes Darul Ilmi mampu menghasilkan santri-santri yang tidak hanya unggul dalam bidang keilmuan keagamaan namun juga di bidang keilmuan umum yang dapat memenuhi kebutuhan masyarakat di berbagai sektor kehidupan masyarakat.

Sementara itu, ada juga masyarakat sekitar yang tidak memasukkan anak-anaknya ke ponpes Darul Ilmi hal ini dikarenakan biaya yang dikeluarkan untuk mendaftar dan iuran bulanan terbilang cukup mahal. Memang sebagian masyarakat Landasan Ulin Barat adalah keluarga dengan ekonomi menengah ke bawah. Ibu Uswatun dan beberapa masyarakat yang lain, senada mengatakan bahwa sebenarnya ingin sekali memasukkan anaknya ke ponpes Darul Ilmi karena melihat santri-santri yang menempuh pendidikan di sana memiliki keilmuan dan keterampilan baik dalam ilmu agama maupun ilmu umum.

Senada dengan pendapatnya Jumiati (2021) yang mengatakan "saya sebenarnya ingin sekali anak saya bersekolah di sana jika melihat para santri pintar membaca Al-qur'an. Tapi terkendala dengan biaya pendaftarannya itu." Mengenai hal ini, bapak Sarmawi selaku bendahara umum ponpes Darul Ilmi menjelaskan jika biaya administrasi baik itu pendaftaran awal dan iuran bulanan digunakan untuk memenuhi kebutuhan para santri itu sendiri. Biaya pendaftaran akan dialokasikan untuk menyediakan lemari, kasur, kitab-kitab, buku pelajaran, seragam sekolah pondokkan, seragam untuk sekolah umum, tempat makan dan uang bangunan. Sedangkan untuk iuran bulanan diperuntukkan sebagai pembayaran makan santri, listrik, air dan penggajian guru-guru. Tentunya, pihak pondok pesantren akan terus berusaha untuk mengembangkan pendidikan yang murah dan berkualitas, sehingga harapan masyarakat dapat terwujud dengan mendapati anak-anaknya mampu unggul dalam bidang ilmu agama dan akademik serta keterampilan-keterampilan lain yang bisa menunjang kehidupan dimasa yang akan datang.

\section{SIMPULAN}

Berdasarkan hasil pengamatan, analisis data dan konfirmasi data untuk mengetahui kebenaranya, mengenai tanggapan masyarakat terhadap pendidikan di ponpes Darul Ilmi Banjarbaru dapat penulis ambil kesimpulan sebagai berikut: ponpes Darul Ilmi masih dipandang mampu menjaga eksistensinya oleh masyarakat sebagai lembaga pendidikan di tengah-tengah masyarakat dan selalu berusaha meningkatkan kualitas pendidikan sehingga 


\section{Muhammad Efendi, Kukuh Ranom Prayoga, Muniratul Mukaramah}

dapat memenuhi harapan masyarakat terhadap perbaikan kehidupan beragama. Selanjutnya, keberadaan ponpes Darul Ilmi dianggap tidak hanya sebagai lembaga pendidikan namun juga sebagai panutan beragama serta memberikan pembinaan dan pendidikan bagi santri dan masyarakat sekitar. Selanjutnya dalam hal keberadaan masyarakat dilingkungan ponpes masih ada yang tidak menyekolahkan anak-anaknya ke lembaga tersebut, dikarenakan terkendala biaya pendaftaran dan iuran bulanan yang harus dikeluarkan. Namun dalam hal ini pihak pondok memberikan penjelasan terkait penggunaan dana tersebut.

\section{DAFTAR PUSTAKA}

Arifiah, D. A. (2021). Solusi Terhadap Problematika Pendidikan Dalam Pembelajaran di Pesantren Pada Era Globalisasi. Jurnal Pendidikan, 9(2), 36-43.

Arifin, Z. (2011). Konsep dan Model Pengembangan Kurikulum, Cet. I. PT. Remaja Rosdakarya: Bandung.

Arisanty, D., \& Efendi, M. (2017). Penggunaan Model Pembelajaran Latihan Penelitian untuk Meningkatkan Hasil Belajar Geografi MA Darul Ilmi Banjarbaru, Kalimantan Selatan. Prosiding Konvensyen Kebangsaan Sekolah Kluster Kecemerlangan, 264.

Efendi, M. (2014). Pengaruh model pembelajaran latihan penelitian terhadap hasil belajar geografi siswa SMA. Universitas Negeri Malang.

Efendi, M., Masriyah, M., \& Riadi, S. (2020). Islamic Contribution In The Covid-19 Pandemic Viewed From History.

Fakhruddin, A. (2011). Prinsip-Prinsip Manajemen Pendidikan Islam dalam Konteks Persekolahan. Jurnal Pendidikan Agama Islam-Ta'lim, 9(2), 199-212.

Herdiana, Y., Kosim, C. A., Erihadiana, M., \& Syah, M. (2021). Transformasi Manajemen Masyarakat di Lingkungan Pesantren. Jurnal Pendidikan dan Pengajaran Guru Sekolah Dasar (JPPGuseda), 4(2), 110-118.

Indonesia, P. R. (2003). Undang-Undang Republik Indonesia Nomor 20 Tahun 2003 Tentang Sistem Pendidikan Nasional. Jakarta.

Jamal, N. (2015). Transformasi Pendidikan Pesantren dalam Pembentukan Kepribadian Santri. TARBIYATUNA, 8(2), 64-100.

Kurniawan, Y. (2021). Manajemen hubungan masyarakat dalam mengembangkan pondok pesantren: Penelitian di pondok pesantren Nurul Falah Cililin Bandung Barat. Uin sunan gunung djati bandung.

Miles, B. M., \& Huberman, M. A. (1992). Analisis Data Kualitatif (Alih bahasa oleh Tjetjep Rohendi. Jakarta: UI Press.

Nasution, N. A. (2020). Lembaga Pendidikan Islam Pesantren. Al-Muaddib: Jurnal Ilmu-Ilmu Sosial dan Keislaman, 5(1), 36-52.

Pandiangan, A. P. B. (2019). Penelitian Tindakan Kelas: Sebagai Upaya Peningkatan Kualitas Pembelajaran, Profesionalisme Guru Dan Kompetensi Belajar Siswa. Deepublish.

Pratama, T. P. (2014). Peranan Pondok Pesantren Hudatul Muna Ii Ponorogo Dalam Pengembangan Pendidikan Santri Untuk Menghadapi Tantangan Di Era Globalisasi. SOSIALITAS; Jurnal Ilmiah Pend. Sos Ant, 5(1).

Prayoga, K. R. (2021). Persepsi Masyarakat Terhadap Pendidikan Agama Islam di Pondok Pesantren Darul Ilmi Banjarbaru. FTK-UIN Antasari: Banjarmasin. 


\section{Tanggapan Masyarakat Terhadap Pondok Pesantren Darul Ilmi ...}

Shiddiq, A. (2015). Tradisi Akademik Pesantren. TADRIS: Jurnal Pendidikan Islam, 10(2), $218-229$.

Sugiyono. (2008). Metode penelitian pendidikan:(pendekatan kuantitatif, kualitatif dan $R \&$ D). Alfabeta.

Suhardi, M., \& Irawan, M. A. (2015). Peran Serta Masyarakat dalam Pengembangan Pondok Pesantren (Studi Kasus di Pondok Pesantren Yanmu NW Praya Lombok Tengah NTB). Jurnal Kependidikan, 14(4), 375-383.

Suharni, S., \& Haramen, M. (2020). Dampak Negatif Pergaulan Bebas Terhadap Generasi Muda Menurut Tinjauan Pendidikan Agama Islam. Madrasatuna, 1(1), 27-46.

Syafe'i, I. (2017). Pondok pesantren: Lembaga pendidikan pembentukan karakter. $A l$ Tadzkiyyah: Jurnal Pendidikan Islam, 8(1), 61-82.

Tolib, A. (2015). Pendidikan di Pondok Pesantren Modern. Risâlah, Jurnal Pendidikan Dan Studi Islam, 2(1), 60-66. 